\title{
ヒト培養血管内皮細胞の $\mathrm{PGI}_{2}$ 産生に及ぼす \\ アンギオテンシン変換酵素関連物質の影響 \\ 単離血管との比較
}

$\begin{array}{lrlllll}\text { 沢田 } & \text { 昌平* } & \text { 高松 } & \text { 一* } & \text { 前防 } & \text { 則彦* } & \text { 豊田 武夫* } \\ \text { 过 } & \text { 肇* } & \text { 林 } & \text { 謙宏* } & \text { 中川 } & \text { 雅夫* } & \text { 伊地知浜夫* }\end{array}$

\section{Relationship between $\mathrm{PGI}_{2}$ generation and angiotensin \\ I-converting enzyme related substances in cultured \\ human vascular endothelial cells and aortic rings}

\author{
Shohei SAWADA*, Hajime TAKAMATSU*, Norihiko MAEBO*, \\ Takeo TOYODA*, Hajime TSUJI*, Kenhiro RIN*, \\ Masao NAKAGAWA* and Namao IJICHI*
}

Key word: endothelial cells, prostacyclin, ACE, angiotensin II , bradykinin

The effects of angiotensin I (AI) -converting enzyme (ACE) linked substances upon $\mathrm{PGI}_{2}$ generation were investigated using cultured human vascular endothelial cells and rat aortic rings.

Endothelial cells were obtained from human umbilical cord vein and cultured by the modified method of Jaffe et al. $\mathrm{PGI}_{2}$ level was measured by radioimmunoassay of its stable metabolite 6-keto $\mathrm{PGF}_{1 \alpha}$, and $\mathrm{ACE}$ activity was assayed by Lieberman's method.

In the endothelial cells, addition of $\mathrm{AI}$ or bradykinin (BK) enhanced $\mathrm{PGI}_{2}$ generation and also increased ACE activity in the culture medium, but angiotensin II (AII) did not show any effect. Captopril inhibited both of $\mathrm{PGI}_{2}$ generation and $\mathrm{ACE}$ activity in a dose dependent manner, but the enhancement of $\mathrm{PGI}_{2}$ generation by $\mathrm{AI}$ or BK was not affected by the pretreatment with captopril. Meanwhile in the rat aortic rings, $\mathrm{AI}, \mathrm{AII}$, and $\mathrm{BK}$ enhanced $\mathrm{PGI}_{2}$ generation but captopril decreased $\mathrm{PGI}_{2}$ generation in its higher concentration $\left(10^{-3} \mathrm{M}\right)$, and at the same time mechanical stimulation enhanced $\mathrm{PGI}_{2}$ generation. But in the aortic rings whose endothelium was rubbed with blade, $\mathrm{PGI}_{2}$ generation and $\mathrm{AII}$ induced $\mathrm{PGI}_{2}$

* 京都府立医科大学第二内科 [干602 京都市上京区河原町通り広小路上ル The Second Department of Internal Medicine, Kyoto Prefectural University of Medicine, Kyoto, Japan. 
enhancement remarkably decreased.

Through these results it was suggested that conversion of AI to AII by ACE was suspected not to cause the enhancement of $\mathrm{PGI}_{2}$ generation in the endothelial cells, and that the enhanced $\mathrm{PGI}_{2}$ generation of aortic rings by AII was considered to be due to interaction of smooth muscle cells and endothelial cells. The previously reported hypothesis that captopril enhanced $\mathrm{PGI}_{2}$ generation by the accumulation of AI or BK via ACE inhibition, was not confirmed in this experimental system, and captopril was proved to inhibit $\mathrm{PGI}_{2}$ generation directly. It was rather suggested that the enhanced $\mathrm{PGI}_{2}$ generation in the endothelial cells by $\mathrm{AI}$ or BK was probably controlled by their ACE activation, as an autoregulation mechanism.

\section{はじめに}

生体の血圧維持機構に㧤いては, 交感神経系, renin-angiotensin (以下 RA) 系, kallikreinkinin (KK) 系, ならびに prostaglandin (PG) 系などが相互に関与していると考兄られ従来よ り種々の脈管作動物質の作用機序に怙ける上記 諸物質の関与が検討されてきているが，その作 用機序に抢ける $\mathrm{PGI}_{2}$ 産生元進作用の関与の有 無は実験系あるいは種属の差異により結果が一 致しないものもあり，一定の結論に至っていな いのが現状である.

Moncada らは血管壁の $\mathrm{PGI}_{2}$ 産生の主座とし ての内皮細胞の重要性を報告している1)が一方 acetylcholine, bradykinin (BK), calcium ionophore などの脈管作動物質による単離血管の弛 緩反応に损いては血管内皮細胞の存在が必要で あることが報告されて扣り ${ }^{2)}$ ，また Furchgot $\mathrm{t}^{3)}$ は血管弛緩作用を示す endothelium derived relaxing factor の内皮での存在を示唆してい る.このように血管壁の弛緩反応に拈ける内皮 細胞の重要性及び血管内皮と平滑筋の相互作用 の重要性が近年注目されて括り血管壁の $\mathrm{PGI}_{2}$ 産生を検討する際に，内皮細胞と単離血管との $\mathrm{PGI}_{2}$ 産生を比較検討することは有意義である と考穴られる.

そこで今回われわれは血管壁 $\mathrm{PGI}_{2}$ 産生に及 ぼす BK, angiotensin I (A I ), angiotensin II (AII) ならびに captopril などのアンギオテン シン変換酵素 (ACE) 関連物質の影響について $\mathrm{ACE}$ 活性を含めて, ヒト臍帯静脈培養内皮細
胞およびラット胸部大動脈輪を用いて比較検討 し, 若干の考察を加えた.

\section{I. 方 法}

\section{1. 血管内皮細胞培養法とその同定}

ヒト臍帯静脈内皮細胞は既報4)の方法により 培養し, confluent 形成した初代培養細胞を以 下の実験に供した。な扮細胞質に Weibel-Palade body の存在を確認することにより内皮細 胞と同定した.

\section{2. $\mathbf{P G I _ { 2 }}$ 並びに ACE 活性の測定法}

$\mathrm{PGI}_{2}$ 量は New England Nuclear 社製 6keto $\mathrm{PGF}_{1 \alpha}\left[{ }^{3} \mathrm{H}\right]$ RIA kit ${ }^{5)}$ を使用し 6-keto $\mathrm{PGF}_{1 \alpha}$ 量として測定し, ACE 活性は Lieber$\operatorname{man}^{6)}$ の方法に準じて測定した.

3. 内皮細胞の $\mathbf{P G I}_{2}$ 産生ならびに保生液中 の ACE 活性の経時的変化の検討法

confluent 形成した初代培養細胞を Buffer A $\left(150 \mathrm{mM} \mathrm{NaCl}, 5 \mathrm{mM} \mathrm{KCl}, 1.8 \mathrm{mM} \mathrm{CaCl}_{2}\right.$, $5 \mathrm{mM}$ glucose, $1 \mathrm{mM} \mathrm{MgCl}_{2}, 10 \mathrm{mM}$ HEPES, $\mathrm{pH}$ 7.4）にて 2 回洗浄後, Buffer A $500 \mu l$ を 添加し, $37^{\circ} \mathrm{C}$ で保生し, 保生液中に産生遊離 される $\mathrm{PGI}_{2}$ 量ならびに $\mathrm{ACE}$ 活性を測定し, その経時的変化を検討した。

4. 内皮細胞の $\mathbf{P G I}_{2}$ 産生, 並びに保生液中 の ACE 活性に及ぼす脈管作動物質の影 響の検討

内皮細胞の保生系に captopril $\left(10^{-3} \sim 10^{-9} \mathrm{M}\right)$, BK (Sigma) $\left(10^{-6}, 10^{-8} \mathrm{M}\right)$, A I (Sigma) $\left(10^{-6}\right.$, $\left.10^{-8} \mathrm{M}\right)$ 拈よび A II (Sigma) $\left(10^{-4}, 10^{-6} \mathrm{M}\right)$ を 添加後, 同様に保生し $\mathrm{PGI}_{2}$ 量ならびに $\mathrm{ACE}$ 

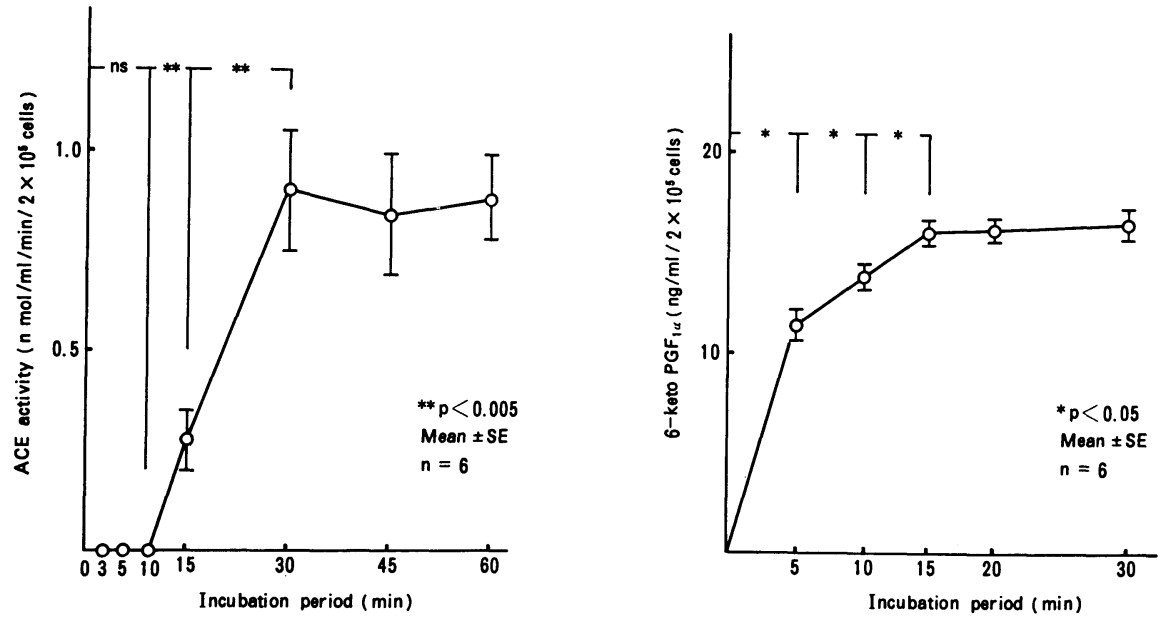

Fig. 1a, 1b ACE activity and $\mathrm{PGI}_{2}$ generation in the medium of cultured human vascular endothelial cells

活性を測定した.

\section{5. 内皮細胞の $\mathrm{PGI}_{2}$ 産生に及ぼす captopril 前処置の影響の検討法}

内皮細胞を captopril $\left(10^{-5} \mathrm{M}\right)$ 飞て30分間前 処置後, Buffer A にて2 回洗浄し，BK ある いは $\mathrm{AI}\left(10^{-6} \mathrm{M}\right)$ を添加後一定時間保生し， 保生液中の $\mathrm{PGI}_{2}$ 量を測定した.

6. 大動脈ならびに内膜剝離大動脈輪の作 成，保生法

胸部大動脈は体重 200-300 g の Wister 系雄 性ラットよりエーテル麻醉下に摘出し 4 $5 \mathrm{~mm}$ に細切し，承冷生理食塩水中で軽く洗浄後，湿 重量 $2 \mathrm{mg}$ あたり $1 \mathrm{ml}$ の Buffer A を加兄 10 分間 $37^{\circ} \mathrm{C}$ で保生した。大動脈輪を除去後 $1 \mathrm{mM}$ aspirin を $100 \mu l / 1 \mathrm{ml}$ の割合で保生液に添加 乙， $1500 \mathrm{G} ， 15$ 分間の遠心上清を凍 結 保 存後 $\mathrm{PGI}_{2}$ 量を測定した。

前述の如くラット大動脈を摘出後 切開 し, blade にて内膜を鈍的に擦過剝離することによ り内膜を剝離した大動脈輪を作成し，同様の保 生実験に供した。

7. 大動脈輪の $\mathbf{P G I}_{2}$ 産生に及ぼす脈管作動 物翼の影響の検討法

大動脈輪の保生液飞 captopril $\left(10^{-3} \sim 10^{-9} \mathrm{M}\right)$, BK $\left(10^{-6}, 10^{-8} \mathrm{M}\right)$, AI $\left(10^{-6}, 10^{-8} \mathrm{M}\right)$ 牡よび AII $\left(10^{-6}, 10^{-8} \mathrm{M}\right)$ を添加後, 同様に保生し $\mathrm{PGI}_{2}$ 量を測定した.

\section{8. 大動脈輪の $\mathrm{PGI}_{2}$ 産生に及ぼす機械的刺 激の影響の検討法}

大動脈輪に 3 回/秒の機械的振藍 (Taiyo Incubator M-100T) を10分間加兄た場合の $\mathrm{PGI}_{2}$ 量を測定した.

9. 大動脈輪の $\mathrm{PGI}_{2}$ 産生に及ばす内膜と平 滑筋の相互作用の検討法

大動脈輪の内膜存在下なら び に非存在下に おケる，Buffer A のみの添加時ならびに AII $\left(10^{-6} \mathrm{M}\right)$ 添加時の $\mathrm{PGI}_{2}$ 量を測定し比較検討 した.

\section{II. 成 樍}

A. 培養内皮細胞における成樍

1. $\mathrm{PGI}_{2}$ 産生ならびに ACE 活性の経時的 変化

内皮細胞保生液中の ACE 活性は Buffer A のみの添加時には，保生開始15分後に出現しそ の後経時的に増大し，30分後にはほぼプラトー に達した（図 1 a)，また保生液中の $\mathrm{PGI}_{2}$ 産生 量は，保生開始後急増し，15一20分後にはほぼ プラトーに達した（図１ｂ）。すなわち保生液中 の $\mathrm{ACE}$ 活性の増大は $\mathrm{PGI}_{2}$ 産生のそれより やや遅れることが示された。な拈以後の実験に 打いて $\mathrm{ACE}$ 活性ならびに $\mathrm{PGI}_{2}$ 産生量は保 生開始後30分の時点で比較した。

2. $\mathrm{PGI}_{2}$ 産生, 並びに ACE 活性に及ぼす 

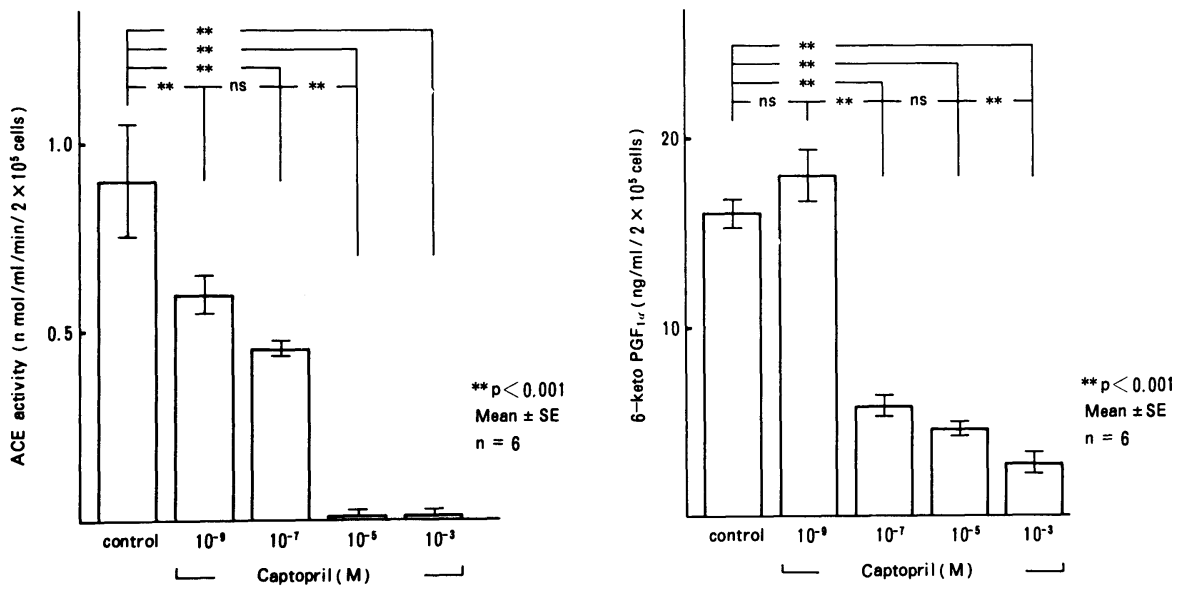

Fig. 2a, 2b Effect of captopril on $\mathrm{ACE}$ activity and $\mathrm{PGI}_{2}$ generation in the medium of cultured human vascular endothelial cells
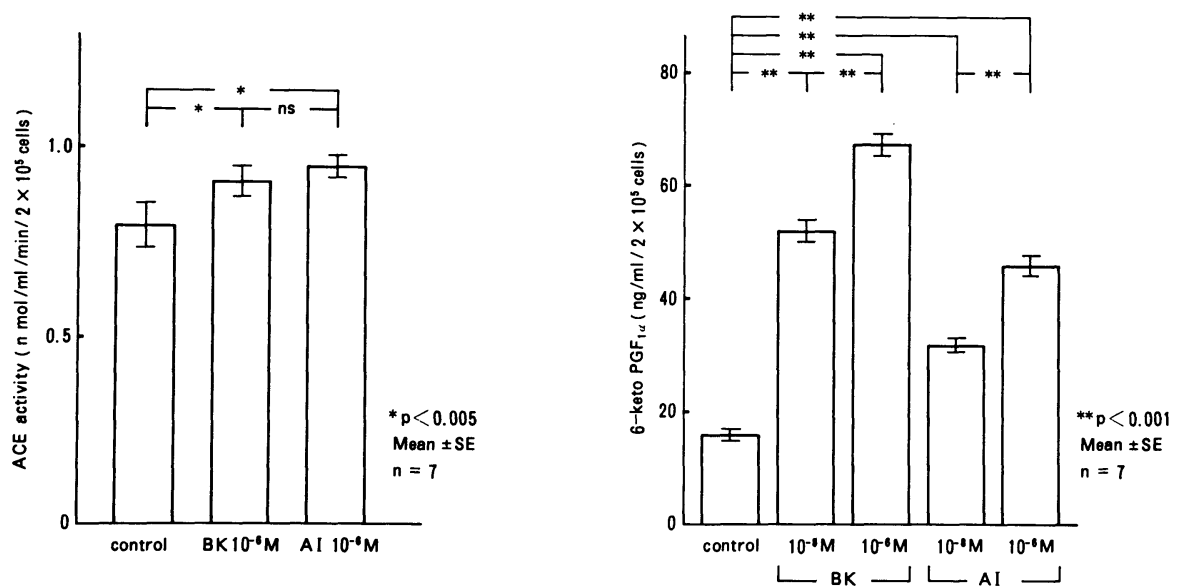

Fig. 3a, 3b Effect of bradykinin (BK) or angiotensin I (AI) on $\mathrm{VCE}$ activity and $\mathrm{PGI}_{2}$ generation in the medium of cultured human vascular endothelial cells

\section{脈管作動物質の影響}

\section{a. Captopril}

captopril は ACE 活性を濃度依存性飞抑制 し， $10^{-5} \mathrm{M}$ 以上の濃度ではほぼ完全に抑 制 し た（図 2 a). 一方 $\mathrm{PGI}_{2}$ 産生を濃度依存性に抑 制した（図 2 b).

b. $\mathrm{BK}$ 抽よび $\mathrm{AI}$

$\mathrm{BK}$ または $\mathrm{AI}$ はそれぞれ $\mathrm{ACE}$ 活性を増大 させ (図 $3 \mathbf{a}$ ), 一方 $\mathrm{PGI}_{2}$ 産生量も $\mathrm{BK}$ また は AI の添加濃度依存性に有意に増量させた (図 $3 \mathbf{b}$ ).

\section{c. AII}

AII は $\mathrm{ACE}$ 活性並びに $\mathrm{PGI}_{2}$ 産生量には影
響を及ぼさなかった（図 $4 \mathrm{a}, 4 \mathrm{~b}$ ).

3. $\mathbf{B K}$ および $\mathbf{A I}$ による $\mathbf{P G I}_{2}$ 産生亢進作 用に及ばす captopril 前処置の影響 captopril 前処置下では $\mathrm{BK}$ による $\mathrm{PGI}_{2}$ の 産生は量としては著減したが, $\mathrm{BK}$ による $\mathrm{PGI}_{2}$ 産生の促進作用は同様に認められ，その増加率 は captopril 非添加時と有意差を認めなかった (表 1 ).

保生系への $\mathrm{AI}$ の添加による $\mathrm{PGI}_{2}$ 産生増大 率は BK の場合之同様 captopril の存否により 影響されなかった（表 1 ）.

B. 大動脈輪における成績

1. $\mathrm{PGI}_{2}$ 産生に及ぼす脈管作動物質の影響 

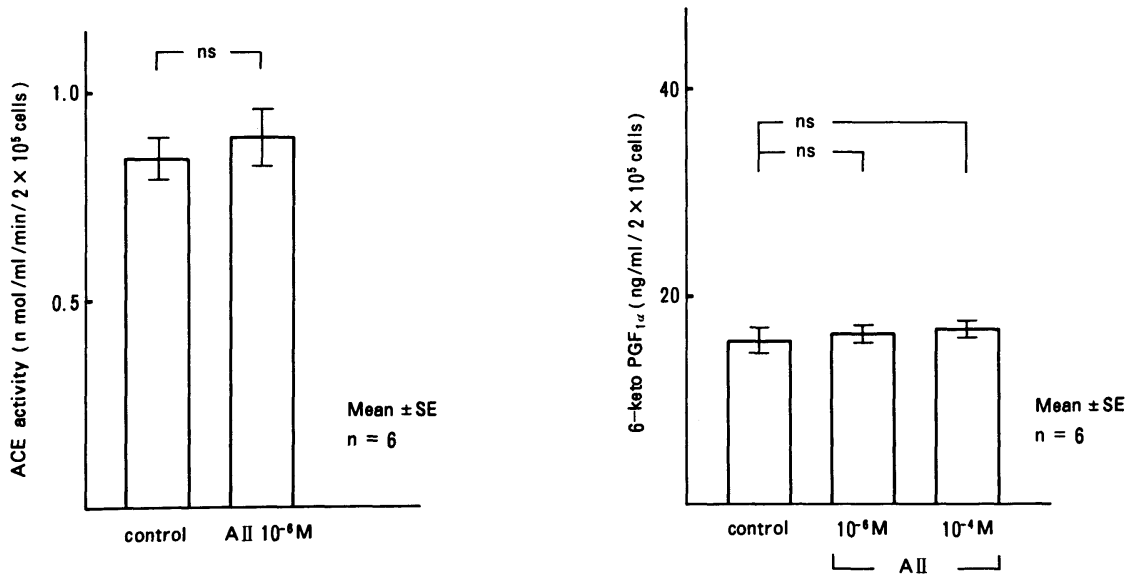

Fig. 4a, 4b Effect of angiotensin II (AII) on ACE activity and $\mathrm{PGI}_{2}$ generaton in the medium of cultured cultured human vascular endothelial cells

Table 1 Effect of pretreatment with captopril on enhanced $\mathrm{PGI}_{2}$ generation induced by bradykinin (BK) or angiotensin $\mathrm{I}(\mathrm{AI})$ in the medium of cultured human vascular endothelial cells

\begin{tabular}{lccc}
\hline $\begin{array}{c}\text { Pretreatment } \\
\text { with captopril } \\
\left(10^{-5} \mathrm{M}, 30 \mathrm{~min}\right)\end{array}$ & 6-keto PGF $\mathrm{a} a$ \\
$\left(\mathrm{ng} / \mathrm{ml} / 2 \times 10^{5}\right.$ cells $)$ & AI \\
\hline non-treated & $16.11 \pm 0.64$ & $70.33 \pm 0.76$ & $46.32 \pm 0.33$ \\
& $(100 \%)$ & $(432 \pm 21 \%)$ & $(288 \pm 20 \%)$ \\
\hline & & BK & \\
\hline treated & $4.84 \pm 0.14$ & $21.55 \pm 0.85$ & $14.28 \pm 0.76$ \\
& $(100 \%)$ & $(484 \pm 31 \%)$ & $(321 \pm 26 \%)$ \\
\hline
\end{tabular}

$* p<0.001$, Mean $\pm S E, n=6$

a. Captopril

$10^{-5} \mathrm{M}$ 以下の低濃度の captopril では大動脈 の $\mathrm{PGI}_{2}$ 産生に影響しなかったが， $10^{-3} \mathrm{M}$ の高 濃度では減少した。

b. AI, AII 䘜よび BK

$\mathrm{AI}, \mathrm{AII}$ 和よび BK は濃度依存性に大動脈 の $\mathrm{PGI}_{2}$ 産生を増大させた（図 5 ）.

2. $\mathbf{P G I}_{2}$ 産生に及ぼす機械的刺激の影響 大動脈への毎秒 3 回の機械的振盙は $\mathrm{PGI}_{2}$ 産 生を著増させた（図 5 ）.

3. $\mathbf{P G I}_{2}$ 産生に及ぼす内膜と平滑筋の相互 作用

大動脈の内膜を剝離した場合には $\mathrm{PGI}_{2}$ の基
礎産生は減少したが,一方 AII 添加による $\mathrm{PGI}_{2}$ 産生増大作用も内膜剥離により著減した（表 2 ).

\section{III. 考案}

Moncada, Vane ら ${ }^{1)}$ にる $\mathrm{PGI}_{2}$ の発見以 来，血管挔張作用などの生理活性が明らかにさ れ, vascular homeostasis の維持機構における この重要性が確認されている. 一方従来より血 管壁の $\mathrm{PGI}_{2}$ 産生を六進させると考えられてい る $\mathrm{BK}$ 扤よび $\mathrm{AII}$ 等の血中濃度は $\mathrm{ACE}$ 活性 の増減により調節されているので，これらをる 含めた $\mathrm{ACE}$ 関連物質による $\mathrm{PGI}_{2}$ の産生遊離 


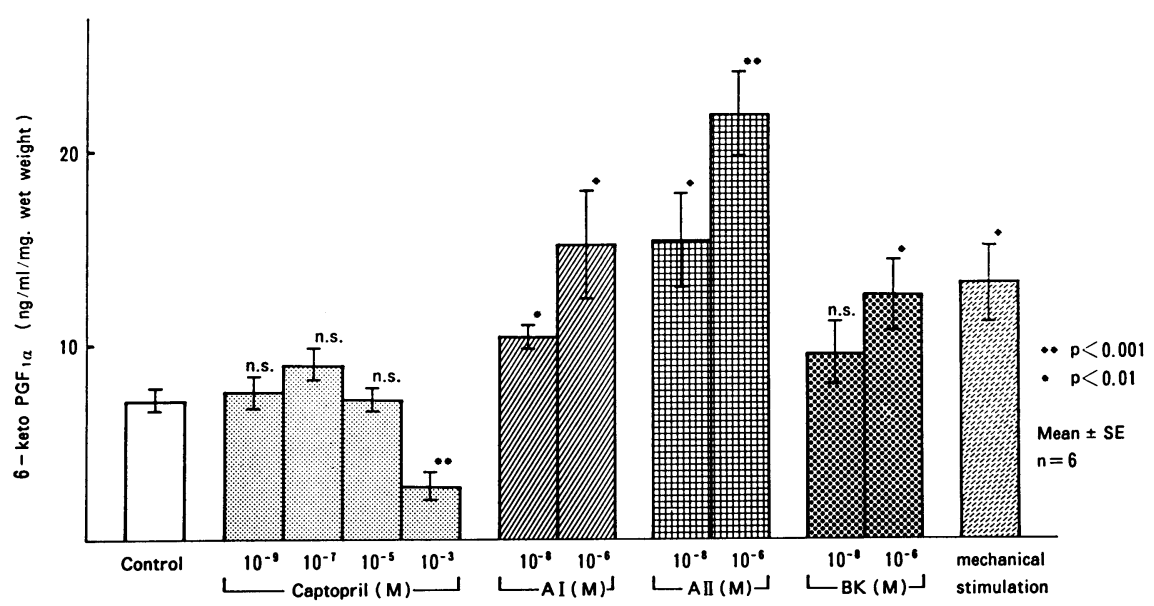

Fig. 5 Effect of captopril, angiotensin I, II (AI, AII), bradykinin (BK) or mechanical stimulation on $\mathrm{PGI}_{2}$ generation in rat aortic rings

機構は $\mathrm{ACE}$ 活性の変動により修飾 をらけるものと推測され, この観点 から内皮細胞での $\mathrm{PGI}_{2}$ の産生遊離 機構を検討することが望ましいと考 えられる、しかるに本実験では，培 養内皮細胞の保生液中に $\mathrm{ACE}$ 活性 を認め, しかも captopril によりこ れが抑制されることが確認されたの でヒト臍帯静脈の内皮細胞 も ACE の産生母地の一つであると考えられ た. 従って ACE 関連物質の $\mathrm{PGI}_{2}$ Table 2 Role of endothelium in the $\mathrm{PGI}_{2}$ generation by AII in rat aortic rings

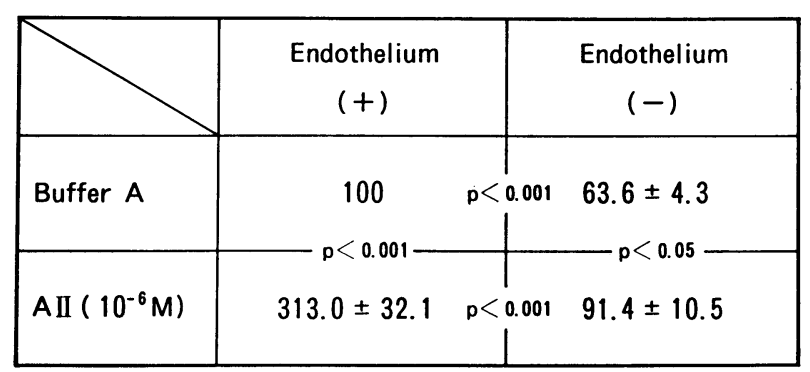

( $\%$ change, Mean $\pm S E, n=6$ ) の産生に及ぼす影響を $\mathrm{ACE}$ 活性をも含めて細 胞レベルで検討しらる単離培養血管内皮細胞を 用いた実験系は有用と考えられる.

しかし, 生体内での種々の脈管作動物質によ る様々な生理活性の発現は overall としての反 応であり，この意味に打いて血管壁の $\mathrm{PGI}_{2}$ 産 生遊離機構を whole vessel (大動脈輪) のレベ ルで総合的に評価することも重要であり，ラッ ト大動脈輪を用いた実験系と培養内皮細胞を用 いた実験系とに拈けるこれらの脈管作動物質の 作用態度を比較検討することは血管壁の主な構 成細胞である内皮細胞と平滑筋細胞との相互関 係を知る上で有意義と考えられる.

ヒト臍帯静脈内皮細胞およびラット大動脈輪 に拈いて, $\mathrm{BK}$ 並びに $\mathrm{AI}$ はともに $\mathrm{PGI}_{2}$ 産生 を増大させたが， $\mathrm{BK}$ の $\mathrm{PGI}_{2}$ 産生充進作用に ついては内皮細胞就よび単離血管に执いても既
に報告されておりて本成績もこれを支持すると 考兄らる. しかし $\mathrm{AI}$ の $\mathrm{PGI}_{2}$ 産生方進作用 は, 従来は AI から AII への変換により生ずる とされているが, 内皮細胞に执いては AII の $\mathrm{PGI}_{2}$ 産生六進作用が認められなかったことよ り, AI から AII への変換を介するものではな く, AI 自体の内皮細胞に対する直接的な刺激 作用によるものと推測されたが，その詳細なメ カニズムは不明である.

従来 captopril の降圧機序に括ける $\mathrm{PGI}_{2}$ 産 生充進作用の関与については多くの報告がなさ れているが，近年 Cinotti ら ${ }^{8)}$ は captopril 経口 投与後の尿中 PG を測定する場合には, 種差, 日内変動, 精腺, 年齢のマッチング等がなけれ ばその data には信頼性がないことを報告して おり，それ以前の captopril の経口投与後に尿 中 PG が増加するとの報告にはこれらの配慮が 


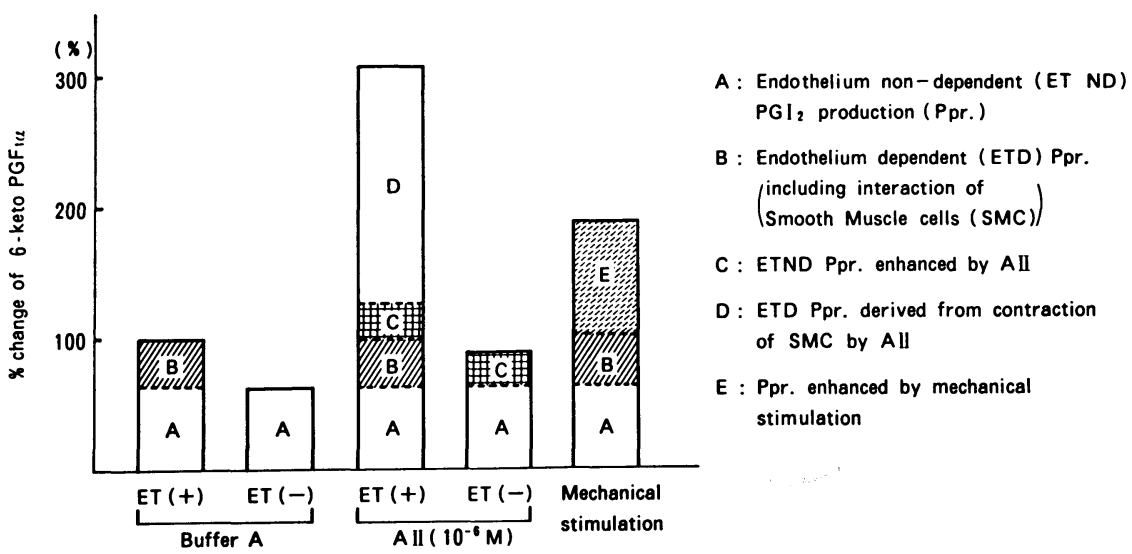

Fig. 6 Role of endothelium in the $\mathrm{PGI}_{2}$ generation by $\mathrm{AII}$ in rat aortic rings

そしいとしているため，われわれは種差以外の 上記諸因子の関与が乏しいと考兄られる内皮細 胞ならびに大動脈輪を用いて検討した.

従来より captopril の降圧機序には BK の蓄 積に基づく $\mathrm{PGI}_{2}$ 産生六進作用の関与が報告さ れている9)ので，内皮細胞に扔いて検討したと ころ, captopril 前処置時には $\mathrm{BK}$ による $\mathrm{PGI}_{2}$ の産生量は著減したが， $\mathrm{BK}$ にる $\mathrm{PGI}_{2}$ 産生 の促進作用は認められ，その増加率は captopril 非添加時と差を認めなかったため， captopril の 降圧機序の一つとして ACE の阻害に基づく, $\mathrm{BK}$ の蓄積を介する $\mathrm{PGI}_{2}$ 産生の増大による機 序は否定的と考学られた。

また本実験系では BK のみならず $\mathrm{AI}$ によっ ても $\mathrm{PGI}_{2}$ 産生は克進したので, captopril 添加 による $\mathrm{AI}$ の蓄積を介する $\mathrm{PGI}_{2}$ 産生六進作用 の発現が生じうるかどうかを検討したところ， 保生系への $\mathrm{AI}$ の添加による $\mathrm{PGI}_{2}$ 産生増大率 は BK の場合と同様 captopril の存否により影 響されなかったため, captopril 添加による AI の蓄積を介する $\mathrm{PGI}_{2}$ 産生元進作用の発現は否 定的と考えられた.

また， captopril は内皮細胞执よび大動脈輪の $\mathrm{PGI}_{2}$ 産生を増大させず，前者ではむしろ著明 に抑制した。ささらに内皮細胞では captopril 前 処置により, $\mathrm{BK}$ 及び $\mathrm{AI}$ による $\mathrm{PGI}_{2}$ 産生の 増大効果が認められなかったことより, captopril の降圧機序の一つとして ACE の阻害に基 づく, $\mathrm{BK}$ および $\mathrm{AI}$ の蓄積を介する $\mathrm{PGI}_{2}$ 産
生の増大による機序は否定的と考えられ，むし ろ captopril は $\mathrm{PGI}_{2}$ 産生を直接抑制すること が示唆された. Vio ら ${ }^{10)}$ はラット大動脈を用い て captopril が $\mathrm{PGI}_{2}$ 産生を抑制することを報 告して括りまた Lijnen ら ${ }^{11)}$ 女高血圧患者に captopril を経口投与したところ，PG が低下し たことを報告しているが本成績はこれを支持す る. また $\mathrm{BK}$ あるいは $\mathrm{AI}$ は $\mathrm{PGI}_{2}$ 産生を増加 せしめると伴に ACE 活性の増加を惹起させる ので，この活性増大は $\mathrm{PGI}_{2}$ 産生増大の促進因 子としての BK 㧊よび AI の減少を招くことに なり， $\mathrm{PGI}_{2}$ の産生調節因子として $\mathrm{BK}, \mathrm{AI}$ 和 よび ACE の相互関係の重要性を示唆するもの と考觉られる.

ところで, $\mathrm{AII}$ の $\mathrm{PGI}_{2}$ 産生増大効果は内皮 細胞に颃いては認められなかったが，大動脈輪 に打いては認められた。 またこれまでの報告で

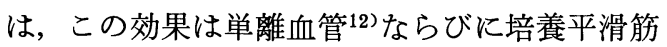
細胞 ${ }^{13)}$ では認められているが，ブタ大動脈内皮 細胞13)を用いた検討では認められていないのが 現状である. この両者の差異の原因については 種差, 実験系の差異も考えられるが, 単離血管 では AII により $\mathrm{PGI}_{2}$ 産生増大を生じない内皮 細胞と, これにより $\mathrm{PGI}_{2}$ 産生増大ならびに収 縮を生じるとされる平滑筋細胞とが近接して存 在するため, AII による大動脈輪の $\mathrm{PGI}_{2}$ 産生 に打ける内膜と平滑筋の相互作用の有無を検討 する目的で内膜剝離の影響を検討した. 内膜剥 離大動脈の $\mathrm{PGI}_{2}$ の基礎産生は減少したが，一 


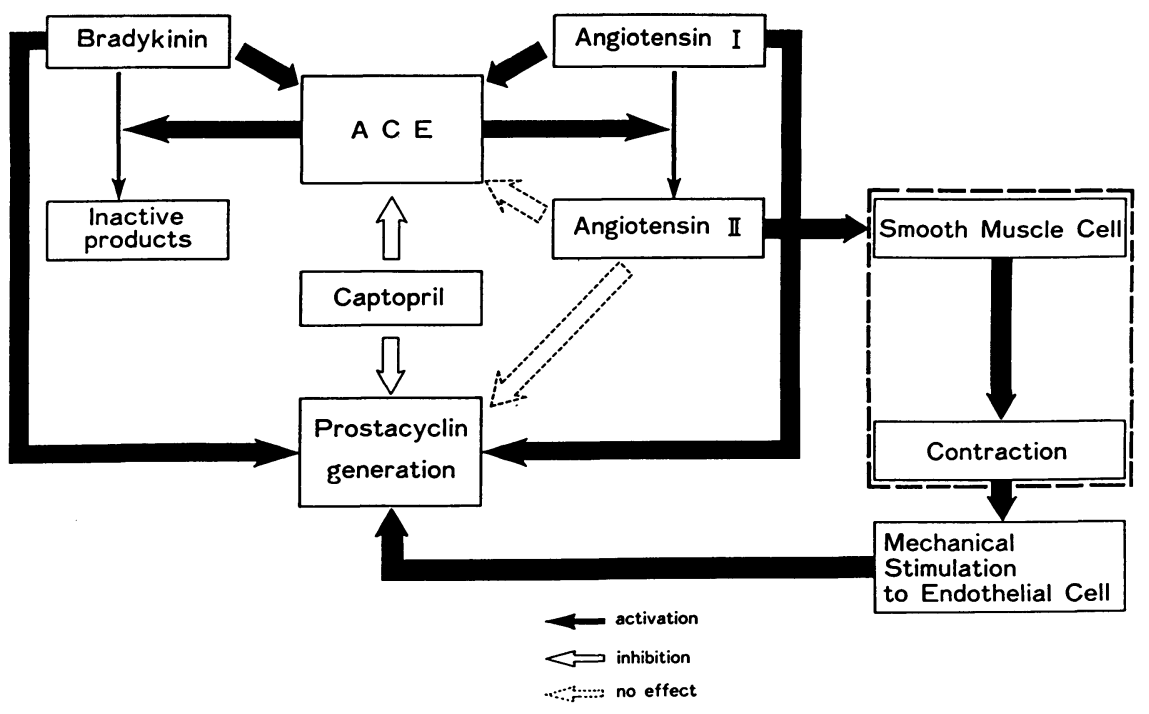

Fig. 7 Interactions of ACE-related substances

方 AII 添加による $\mathrm{PGI}_{2}$ 産生増大作用も内膜剝 離により著減したため, 大動脈の AII による $\mathrm{PGI}_{2}$ 産生増大効果には内膜が必要であること が示された. 佐藤ら ${ }^{12)}$ は単離した犬腎動脈を用 いて内皮細胞を剥離すると $\mathrm{PGI}_{2}$ 産生が有意に 低下することを報告しているがこれは本成績を 支持するものと考㝋られる。

さらに佐藤ら ${ }^{12)}$ は犬腎動脈に拈いて AII によ る産生は血管収縮刺激により生ずることを報告 している. そこで本研究では大動脈輪 $\mathrm{PGI}_{2}$ の 産生に扣よぼす機械的刺激の影響を検討したと ころ, 大動脈輪に機械的刺激を加えた場合には $\mathrm{PGI}_{2}$ 産生は著增した。

したがって大動脈での AII による $\mathrm{PGI}_{2}$ 産生 六進作用に就ける, AII による平滑筋細胞への 直接的な $\mathrm{PGI}_{2}$ 産生刺激作用, 並びそ $\mathrm{AII}$ によ る平滑筋細胞の収縮に基づく内皮細胞への機械 的刺激に基づく内皮細胞での $\mathrm{PGI}_{2}$ 産生増大作 用の関与が示唆された（図6).

ところで AII の $\mathrm{PGI}_{2}$ 産生増大効果が内皮細 胞に打いては認められなかった原因としては AII 受容体が存在しないことによる可能性が考 壳られる. AII 受容体は Goodfriend ら ${ }^{14)}$ が報 告して以来, 種々の組織に括いても存在すると いわれて拉り，Gunther ら ${ }^{15)}$ とより培養平滑筋 細胞に扮いて既に証明され，一般に平滑筋細胞
にはAII 受容体が存在するとされているが，近 年 AII 受容体が存在するとされていたヒト血小 板ならびに単核球に和いては AII 受容体が存在 しないといら報告 ${ }^{16)}$ が認められる。 また Ody ら ${ }^{13)}$ は AII による $\mathrm{PGI}_{2}$ 産生増大作用がブタ大 動脈培養内皮細胞では認められず，一方培養平 滑筋細胞に打いては認められたこと，さらに ${ }^{125}$ I一AII を用いた binding assay によっても 培養内皮細胞では AII 受容体の存在を証明し得 なかったことを報告した. 以上より内皮細胞に おいて AII による $\mathrm{PGI}_{2}$ 産生六進効果が発現し なかった原因として AII 受容体が本細胞には存 在しない可能性が考えられた。

したがって大動脈での AII による $\mathrm{PGI}_{2}$ 産生 六進作用に括いてはAII による平滑筋細胞の収 縮に基づく内皮細胞への機械的刺激に基づく内 皮細胞での $\mathrm{PGI}_{2}$ 産生増大作用の関与が示唆さ れた(図 7 ). すなわち, 内皮細胞と平滑筋細胞 の相互作用は密接かつ重要と考兄られ，今後, 種々の脈管作動物質の作用機序を考える際には 内皮細胞，平滑筋細胞への直接的な作用ととも に両者の相互作用も含めて検討しなければなら ないものと考觉られた。

\section{文献}

1) Moncada, S., Herman, A.G., Higgs, E. A. and 
Vane, J.R.: Differential formation of prostacyclin (PGX or $\mathrm{PGI}_{2}$ ) by layers of the arterial wall an explanation for the antithrombotic properties of vascular endothelium. Thromb. Res., 11; 323 344, 1977.

2) Vanhoutte, P.M. and Rimele, T.J.: Role of endothelium in the control of vascular smooth muscle function. J. Physiol. (Paris), 78; $681 \sim 696,1982$.

3) Furchgott, R.F.: Role of endothelium in responses of vascular smooth muscle. Circ. Res., 53; 557 573, 1983.

4）豊田武夫, 岡野 良, 三上欽司, 金山春洋, 辻 肇, 長村吉朗, 林 謙宏, 貝増勲彦, 中川雅夫. 伊地知浜夫 : ヒト培養血管内皮細肥の $\mathrm{PGI}_{2}$ 産生に及ぼす二，三の薬剤の影響. 血液と脈 管, 14；488～490，1983.

5) Instruction Manual For The measurement of 6-keto-prostaglandin $F_{1 \alpha}$ levels in tissue and biological fluid, Catalog No. NEK-008, New England Nuclear, June 1982, p. 1 14.

6) Lieberman, J.: Elevation of serum angiotensin-converting enzyme (ACE) level in sarcoidosis. Am. J. Med., 59; 365 372, 1975.

7) Hong, S.L.: Effect of bradykinin and thrombin on prostacyclin synthesis in endothelial cells from calf and pig aorta and human umbilical cord vein. Thromb. Res., 18; 787 795, 1980.

8) Cinotti, G.A.: Interaction of renin, kinins and prostaglandins. Hypertension, 1 (Suppl 1.)) 43 51, 1983.

9) Mullane, K.M. and Moncada, S.: Prostacylin mediates the potentiated hypotensive effect of bradykinin following captopril treatment. Eur. J. Pharmacol., 66; 355 365, 1980.

10) Vio, C.P., Guivernau, M., Terrangno. A. and Terrangno, N.A.: Effects of captopril on the biosynthesis of prostaglandins in vitro. Fed. Proc. 40 (Part 1); 702, 1981.

11) Lijnen, P., Fagard, Staessen, J., Verscheuren, L.J. and Amery, A.: Role of various vasodepressor system in the acute hypertensive effect of captopril in man. Eur. J. Clin. Pharmacol., 20; 1 8, 1981.

12) Satoh, H. and Satoh, S.: Prostaglandin E and I production in isolated dog renal arteries in the absence or presence of vascular endothelial cells. Biochem. Biophys. Res. Commun., 118; $873 \sim 876,1984$

13) Ody, C., Seillan, C. Marie, F.R. and Duval, D. : Angiotensin II dose not any specific prostaglandin secration in piglet cultured endothelial cells. Thromb. Res., 31; 219 231, 1983.

14) Goodfriend. T.L. and Lin, S.: Receptor for angiotensin I and II. Circ. Res. 17 (Suppl.); I-163 I-170, 1970.

15) Gunther, S., Gimbrone, M.A. and Alexander, R. W.: Identification and characterization of the high affinity vascular angiotensin II receptor in rat mesenteric artery. Circ. Res., 47; $278 \sim 286,1980$.

16) Neyses, L., Locher, R., Wehling, M., Pech, H., Tenschert, W. and Vetter, W. : Angiotensin II binding human mononuclear cells; receptor or fluid endocytosis. Clin. Sci., 66; 608 $\sim 612,1984$. 